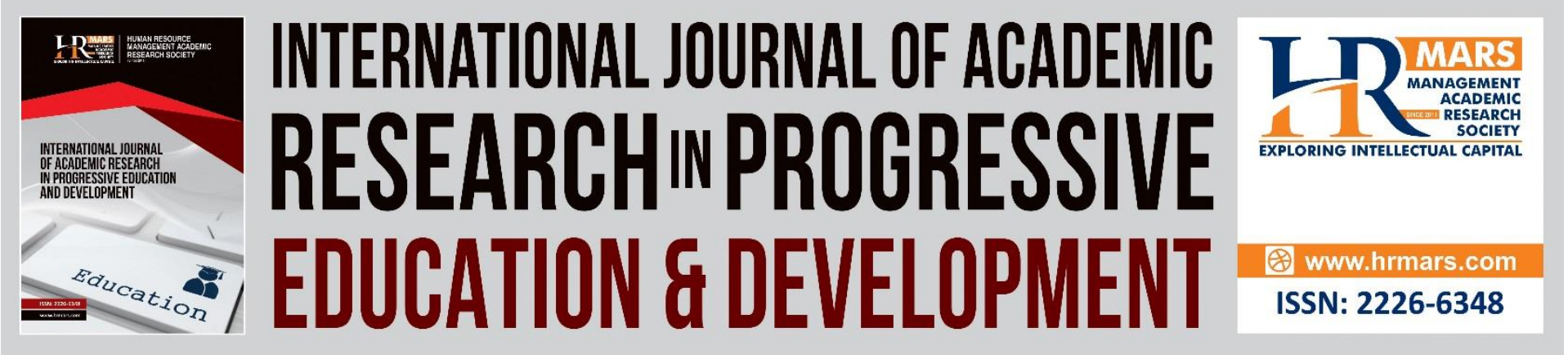

\title{
The Level of Student's Achievement and the Relationship between the PEERS, Nutrition and First Aid Component using MoPPK among National Primary School
}

Faiznur Maisya Binti Annur Sani, Azali Bin Rahmat, Gunathevan a/l Elumalai

To Link this Article: http://dx.doi.org/10.6007/IJARPED/v10-i4/11712

DOI:10.6007/IJARPED/v10-i4/11712

Received: 29 September 2021, Revised: 30 October 2021, Accepted: 17 November 2021

Published Online: 28 November 2021

In-Text Citation: (Sani et al., 2021)

To Cite this Article: Sani, F. M. B. A., Rahmat, A. Bin, \& Elumalai, G. a/l. (2021). The Level of Student's Achievement and the Relationship between the PEERS, Nutrition and First Aid Component using MoPPK among National Primary School. International Journal of Academic Research in Progressive Education and Development, 10(4), 248-257.

Copyright: (C) 2021 The Author(s)

Published by Human Resource Management Academic Research Society (www.hrmars.com)

This article is published under the Creative Commons Attribution (CC BY 4.0) license. Anyone may reproduce, distribute, translate and create derivative works of this article (for both commercial and non-commercial purposes), subject to full attribution to the original publication and authors. The full terms of this license may be seen

at: http://creativecommons.org/licences/by/4.0/legalcode

Vol. 10(4) 2021, Pg. 248 - 257

Full Terms \& Conditions of access and use can be found at http://hrmars.com/index.php/pages/detail/publication-ethics 


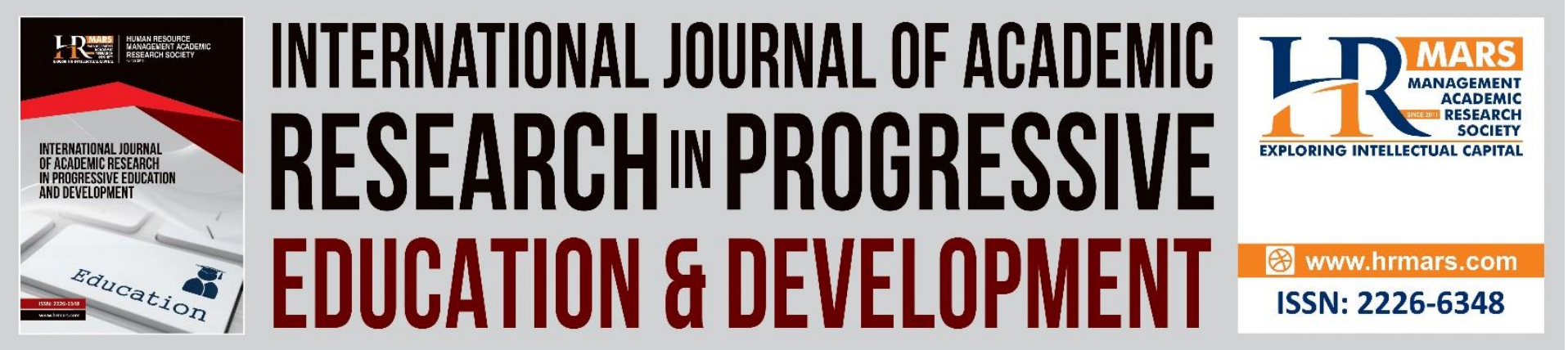

\title{
The Level of Student's Achievement and the Relationship between the PEERS, Nutrition and First Aid Component using MoPPK among National Primary School
}

\author{
Faiznur Maisya Binti Annur Sani \\ Universiti Pendidikan Sultan Idris, Tanjong Malim, Perak. \\ Email: qequr4@gmail.com
}

\begin{abstract}
Azali Bin Rahmat
Fakulti Sains Sukan dan Kejurulatihan, Universiti Pendidikan Sultan Idris, Tanjong Malim, Perak.

Email: azali@fsskj.upsi.edu.my

\section{Gunathevan a/l Elumalai}

Fakulti Sains Sukan dan Kejurulatihan, Universiti Pendidikan Sultan Idris, Tanjong Malim, Perak.

Email: gunathevan@fsskj.upsi.edu.my
\end{abstract}

\begin{abstract}
This study was conducted to determine the achievement level of component PEERS, Nutrition and First Aid in Health Education subject among Year Four student in primary school and the relationships between the component of Health Education Assessment Module (MoPPK). This module is developed for the teachers to learn and facilitate the teaching of topics on the subjects of Health Education on the Malaysian school syllabus. A total of 33 students from Georgetown Penang Division were selected as participants in this study. Results showed all the students are at the 'excellent' and 'good' level in all given subtopic of every component; i) PEERS:81.24\% 'excellent' and mean $=14.84$, ii) Nutrition: $79.36 \%$ 'good' and mean $=16.82$, iii) First Aid: $81.04 \%$ 'excellent' and mean $=12.41$. The overall component mean was at a 'excellent' level of 14.69. Meanwhile, for correlation using Pearson Product Moment showed there is a positive and significant relationship between all the component in MoPPK. This means that in the components used in the module is very helpful for students to improve their level of mastery in the subject of Health Education
\end{abstract}

Keywords: Achievement, Component, Health Education Assessment Module, Relationships 
DEVELOPMENT

Vol. 10, No. 4, 2021, E-ISSN: 2226-6348 @ 2021 HRMARS

\section{Introduction}

The assessment system in Malaysia has been practiced for a long time to ensure the quality of national education in accordance with the National Education Policy. The reforms made in the assessment system are to increase the level of mastery of students for each subject studied. School-Based Assessment (SBA) is one of the methods introduced by the government to create a holistic assessment system. The use of various strategies and methods is applied in the assessment process to ensure that students reach the level of mastery to the optimum and balanced level of physical, emotional, spiritual and intellectual aspects. Therefore, to produce students who have human capital who think critically and creatively and are able to compete globally, then educational planning needs to be scrutinized.

Assessment in the teaching and learning of Health Education should cover cognitive, psychomotor and affective aspects because it can ensure the mastery of students balanced harmoniously involving all the topics given through the subject. The assessment items used must be in accordance with the learning standards set out in the Health Education Curriculum Standards Document (DSKP). Assessment-based teaching and learning activities need to be enhanced and coordinated to design a complete module to improve student achievement (Munroe, 2017). According to Moore (2018), The content of the assessment modules that are systematically compiled based on the learning model and clear implementation guidelines can provide positive effectiveness towards the set learning objectives. However, there is no such a standard assessment of Health Education used in Malaysia's curriculum (Rahmat et al., 2012) . Therefore, a standardized assessment module for Health Education need to be produced and used by the students to enhance their thinking skill and achievement level towards excellent

The construction of the assessment module should contain components that have a relationship that is related to each other. This is to see the suitability of the components used in line with the learning objectives that the teacher wants to achieve. Therefore, a MoPPK assessment module that meets the standards and standards has been produced and used to obtain student achievement level scores for each subtopic studied. The MoPPK has been shown to be a valid and reliable instrument to measure the student achievement in every component of Health Education subject (Sani et al., 2021). In addition, each topic in this module was evaluated as a whole according to the components that have been set in the DSKP Health Education, namely PEERS, Nutrition and First Aid. These three components have been assessed in a balanced way based on cognitive, psychomotor and affective aspects.

Based on the identified problems, the researchers have obtained student assessment scores through assessment modules that have been generated based on predefined components. A comprehensive assessment was conducted to obtain the overall percentage for formative assessment. This assessment was done as soon as each learning standard had been learned. In addition, a study of the relationship between the components was conducted to see the continuity between the components and the level of usefulness of the MoPPK assessment module.

The purposes of the study are as below:

1. Determine the achievement level of component PEERS, Nutrition and First Aid in MoPPK module. 
DEVELOPMENT

Vol. 10, No. 4, 2021, E-ISSN: 2226-6348 @ 2021 HRMARS

2. Determine the relationships between the component of MoPPK module.

\section{Literature Review \\ Class Based Assessment}

School-based assessment is very efficient compared to the examination system because the features are flexible according to the creativity of teachers as well as assessed with a variety of activities. Whereas the examination system is more to cognitive assessment only and the other two domains namely psychomotor and effective are very poorly assessed in the teaching of learning. According to Panesar-Aguilar and Aguilar (2017), the implementation of assessment for effective learning can increase student motivation. Their study emphasizes on the importance of assessment to students as well as assisting teachers in acquiring strategies, skills and using resources to produce assessment in teaching pedagogy. Furthermore, in the context of assessment for learning, the role of the teacher is important in using a variety of methods to aid student understanding. The same opinion is also supported from other studies with the implementation of assessment for learning aimed at assisting teachers in achieving learning objectives as well as obtaining student feedback (Misyak et al., 2016)

\section{Health Education Component}

Health Education module assessment (MoPPK) was design to meet the requirements of the National Education Philosophy in accordance with the guidelines set out in the Malaysian Education Development Plan (PPPM 2013-2025). In this assessment module covers three components according to different weights namely PEERS (75\%), Nutrition (15\%) and First Aid $(10 \%)$. All these components have been broken down into several subtopics by making all the topics are nine namely Personal and Reproductive Health, Substance Abuse, Mental and Emotional Management, Family, Relationships, Disease, Safety, Nutrition and First Aid. According to the study, all the components used in Health Education are closely related to each other because the application of these components involves the practice of daily life. In addition, the main basis of these components is a healthy lifestyle that should be practiced in each of them, especially among children.

\section{Assessment for Learning (AFL)}

Assessment as learning is a student -oriented assessment process that is assessed on an ongoing basis. Assessment for learning can also be used to look at effectiveness in report preparation and student communication learning. The type of assessment that is often used in schools for this assessment is formative assessment. According to Nkealah and Africa (2019), formative assessment is the most effective aspect of teaching and learning. In their study, formative assessment was conducted to look at academic achievement as well as help students' life skills. Formative assessment is an informal process of providing students with feedback and corrections on students' mistakes and weaknesses during learning such as quizzes, question and answer, written tests or class projects. According to Li Li et. al (2018), the use of formative assessment is more effective and efficient because this process makes it easier to detect students 'weaknesses and strengths. The implementation of formative assessment is also supported by Tur and Urbina (2019) by stating this assessment as a coherent approach to look at student achievement as well as increase self -awareness and self -efficacy 
DEVELOPMENT

Vol. 10, No. 4, 2021, E-ISSN: 2226-6348 @ 2021 HRMARS

\section{Research Methodology \\ Research Design}

This research was conducted using a qualitative approach and the design used is a preexperimental one-shot case study. This design of study has been widely used in other fields of education. In the study of Winarto et. al (2018) have used a one shot case study to see the effectiveness of pocket book production in the learning of conceptual understanding. The learning produced using the pocket book has been proven to improve students' understanding.

Therefore, this study involved the process of running the assessment module MoPPK on a sample as well as testing the Health Education assessment module for Year Four. The sample group involved in this study will be given a treatment which is going learning process through assessment module and followed by measurement.

\section{Participants}

In this study, researchers have selected Year Four students who are from National Primary School as the sample of the study as they went through all the component and activities provided in the assessment module MoPPK. There were 33 Year Four students selected as samples in this study.

\section{Instrument}

Assessment module (MoPPK) was used to assess all components achievement level. There are three components in this assessment module which is PEERS, Nutrition and First Aid. Table 1 showed the sub topic in every component in the MoPPK.

Table 1: Sub Topic in Every Components in the MoPPK

\begin{tabular}{ll}
\hline No & Item \\
\hline 1 & Personal and Reproductive Health \\
2 & Substance Abuse \\
3 & Mental and Emotional Management \\
4 & Family \\
5 & Relationship \\
6 & Disease \\
7 & Safety \\
8 & Nutrition \\
9 & First Aid \\
\hline
\end{tabular}

The criteria used in this assessment module (MoPPK) for assessing student's level component are in percentage achievement level. The level of achievement of student is determined based on scale in Table 2 
Table 2. Level of Achievement

\begin{tabular}{cc}
\hline $\begin{array}{c}\text { Achievement Score } \\
(\%)\end{array}$ & Criteria Level \\
\hline $80-100$ & Excellent \\
$65-79$ & Good \\
$50-64$ & Satisfactory \\
$40-49$ & Reach a minimum level \\
$0-39$ & Did not reach a minimum \\
& level \\
\hline
\end{tabular}

Correlation values were evaluated using table 3 according to the size of the correlation scale according to (Hinkle et al., 1998).

Table 3. Determinants of Correlation Values

\begin{tabular}{cc}
\hline Correlation Value & $\begin{array}{c}\text { The Strength of } \\
\text { Relationships }\end{array}$ \\
\hline$\pm \mathbf{0 . 9 0 - 1 . 0 0}$ & Very high \\
$\pm \mathbf{0 . 7 0 - 0 . 9 0}$ & High \\
$\pm \mathbf{0 . 5 0 - 0 . 7 0}$ & Moderate \\
$\pm 0.30-0.50$ & Low \\
$\pm 0.01-0.30$ & Weak \\
0 & No Relation \\
\hline
\end{tabular}

\section{Data Collection}

A total of 6 teachers from schools selected have been chosen to assess and implement the assessment module. All the participants were assessed in their knowledge of Health Education topics of all components at the end of lesson during the class.

\section{Statistical Analysis}

Descriptive statistics were used to obtain participants achievement level and mean score. Correlation Pearson Product Moment was used to determine the relationships between all the components in MoPPK. All Statistical analysis was done by using Statistical Package for the Social Science (SPSS) software, version 23 (IBM, USA).

\section{Data Analysis}

To determine the level of achievement of component in the MoPPK, the total score that has been performed on each component $(\mathrm{x})$ will be divided by the sum of the actual scores $(\mathrm{y})$ and multiplied by one hundred. Formula the following are as follows:

$$
\frac{\text { Total Achievement Score of Component }(x) \times \quad 100 \%=\text { Level of Achievement }}{\text { Maximum Score of Component }(y)}
$$

\section{Research Findings}

\section{Student Achievement Stages in Components Using the Assessment Module (MoPPK)}

Based on the analysis results, table 4 showed the score of components achievement level that was performed by the students in the assessment given. It was found that students are at the 'excellent' and 'good' level in all given subtopic of every component. At least $81.24 \%$ of 
students are at 'excellent' level with mean 14.84 for PEERS component. Besides that, the nutrition component showed the percentage of $79.36 \%$ students are at 'good' level with mean value 16.82 . Lastly for the first aid component showed $81.04 \%$ of students are at 'excellent' level with mean 12.41. The overall component mean was at a 'excellent' level of 14.69.

Table 4. Level of Student Achievement of Components Using the Assessment Module (MoPPK)

\begin{tabular}{lccc}
\hline Components & $\begin{array}{c}\text { Percentage } \\
\text { (\%) }\end{array}$ & $\begin{array}{c}\text { Average } \\
\text { Mean }\end{array}$ & $\begin{array}{c}\text { Expert } \\
\text { View }\end{array}$ \\
\hline PEERS & 81.24 & & Excellent \\
Nutrition & 79.36 & 80.70 & $\begin{array}{c}\text { Good } \\
\text { Excellent }\end{array}$ \\
\hline
\end{tabular}

The Relationships Between the Component of Assessment Module (MoPPK)

Based on Table 5, shows a correlation analysis of student achievement by school category for the three components in the MoPPK assessment module, namely PEERS, Nutrition and First Aid. The results of Pearson product moment correlation analysis for national primary school showed that there was a moderate and significant positive relationship between the formative test of PEERS and Nutrition components $(r=0.50, p=0.00, p<0.01)$. Meanwhile, the next component relationship showed that there was a high and significant positive relationship between the formative test of PEERS and First Aid components $(r=0.73, p=0.00$, $p<0.01$ ). Finally, the correlation between Nutrition and First Aid components showed a moderate and significant positive relationship $(r=0.58, p=0.00, p<0.01)$. Overall, there is a positive and significant relationship between all the component in MoPPK. This means that in the components used in the module is very helpful for students to improve their level of mastery in the subject of Health Education 
Table. 5 Correlation Analysis of Pupil Achievement by School Category for PEERS, Nutrition and First Aid Components

\begin{tabular}{|c|c|c|c|c|c|}
\hline $\begin{array}{l}\text { Schoo } \\
\text { I } \\
\text { Categ } \\
\text { ory }\end{array}$ & & & PEERS & $\begin{array}{c}\text { Nutritio } \\
n\end{array}$ & $\begin{array}{l}\text { Firs } \\
t \\
\text { Aid }\end{array}$ \\
\hline $\begin{array}{l}\text { Natio } \\
\text { nal } \\
\text { Prima } \\
\text { ry }\end{array}$ & PEERS & $\begin{array}{l}\text { Pearso } \\
\mathrm{n} \\
\text { Correla } \\
\text { tion }\end{array}$ & 1 & $.50 * *$ & $\begin{array}{l}.73 \\
* *\end{array}$ \\
\hline $\begin{array}{l}\text { Schoo } \\
\text { I }\end{array}$ & & $\begin{array}{l}\text { Sig. (2- } \\
\text { tailed) }\end{array}$ & & .00 & .00 \\
\hline \multirow[t]{4}{*}{$N=33$} & $\begin{array}{l}\text { Nutrit } \\
\text { ion }\end{array}$ & $\begin{array}{l}\text { Pearso } \\
\mathrm{n} \\
\text { Correla } \\
\text { tion }\end{array}$ & $.50 * *$ & 1 & $\begin{array}{l}.58 \\
* *\end{array}$ \\
\hline & & $\begin{array}{l}\text { Sig. (2- } \\
\text { tailed) }\end{array}$ & .00 & & .00 \\
\hline & $\begin{array}{l}\text { First } \\
\text { Aid }\end{array}$ & $\begin{array}{l}\text { Pearso } \\
\mathrm{n} \\
\text { Correla } \\
\text { tion }\end{array}$ & $.73 * *$ & $.58 * *$ & 1 \\
\hline & & $\begin{array}{l}\text { Sig. (2- } \\
\text { tailed) }\end{array}$ & .00 & .00 & \\
\hline
\end{tabular}

\section{Discussion}

\section{What is the Student Achievement Stages in Components Using the Assessment Module (MoPPK)?}

Overall, the results of the study showed that the achievement of the level of mastery for formative assessment was at an excellent level for each component of PEERS, Nutrition and First Aid. Nevertheless, the findings show that the mean percentage for the PEERS component is the highest compared to the mean percentage achievement level for the nutrition and first aid components. This shows, students can master the PEERS component where this component is very important because the weighting in the subject of Health Education is very high. Thus, among the most frequently assessed topics in the assessment for the PEERS component is Personal and Reproductive Health which discusses decision -making skills in the context of personal and reproductive health and skills in dealing with internal and external influences affecting personal and reproductive health.

According Maslan and Nor (2020) students achievement will be easier to improve weaknesses in the components that have not been mastered through formative assessment feedback done. In addition, the MoPPK assessment module and assessment score form have been constructed with the information specified in the DSKP of Health Education Revised 2018. Accordingly, all module contents and instruments used have reached the learning standards for each component. As conclusions, the findings obtained for the level of mastery 
DEVELOPMENT

Vol. 10, No. 4, 2021, E-ISSN: 2226-6348 @ 2021 HRMARS

of students in the components of PEERS, nutrition and first aid involving national schools showed excellent performance.

\section{What are The Relationships Between the Component of Assessment Module (MoPPK)?}

Through these findings, overall the relationship between the three components of PEERS, nutrition and first aid shows a positive and significant relationship. This explains that the strength and importance of the three components of the assessment module has a very positive effect in improving the level of mastery of fourth year students. Therefore, in order to achieve an excellent overall mastery level of the Health Education learning standards, the use of the three components is very closely related to each other due to the continuity and relevance between the topics reported a significant relationship.

Therefore, this matter explains that in order to see the level of mastery of a subject, the combination of components through learning standards must be assessed holistically and balanced according to the weighting of the topic through formative and summative assessments (OECD, 2013). If the assessment process only focuses on certain topics, it will be considered not to reach a comprehensive standard and irrelevant because the characteristics of an assessment require all components found in the subject syllabus followed by complete objectives for each learning standard (Lahrichi, 2019). As a result, students will be considered not to have mastered the topic as a whole even if the level of mastery is at a good level.

\section{Conclusion}

In conclusion, it is clear that through the assessment module which covers a comprehensive aspect of cognitive, psychomotor and affective aspects and is assessed continuously based on learning standards is very much in line with the characteristics of the assessment system set in the classroom assessment process and the National Education Philosophy.

In addition, this research has shown the results of the highest percentage of student's achievement in using MoPPK assessment module So it can be said that with the use this assessment module is more than the use of assessment based on the text book. According to the statistical analysis showed that there were positive and significant relationships between all the component in MoPPK. Thus, the MoPPK assessment module used more effective by achieving the standard of assessment in school based on the guidelines set by the Malaysian examination board.

\section{Acknowledgment}

The author would like to express their highest appreciation to all the panel of legal expert contents of the MoPPK Module and appreciation is also given to the academics who have provided guidance and guide in the process of development this assessment module.

\section{References}

Rahmat, A., Jani, J., Salimin, N., Khalid, N. H. M., \& Salleh, O. (2012). COMPREHENSIVE ASSESSSMENT MODULE FOR FIRST AID IN PHYSICAL AND HEALTH EDUCATION. IndeX Copernicus Journal Master List, XII(1), 7.

Sani, F. M. A., Rahmat, A., \& Elumalai, G. (2021). Validity and Reliability of the Health Education Assessment Module (MoPPK) among Primary Students in Malaysia. International Journal of Academic Research in Progressive Education \& Development, 10(1) 2020, Pg. 130 - 138. https://doi.org/10.6007/IJARPED/v10-i1/8378 
Kementerian Pendidikan Malaysia. (2018). Dokumen Standard Kurikulum Pendidikan: Pendidikan Kesihatan, 1-6.

Lahrichi, A. (2019). Study on the Effectiveness of Formative and Summative Assessment Techniques in Education, (February).

Li Li, W., Osman, K., \& Maat, S. M. (2018). Analisis Faktor Pengesahan bagi Instrumen Pengetahuan Guru Matematik Sekolah Rendah dalam Pentaksiran Berasaskan Sekolah. Jurnal Pendidikan Malaysia, 43(3), 11-20.

Maslan, M., \& Nor, M. Y. M. (2020). Kebolehlaksanaan Pentaksiran Bilik Darjah (PBD) Secara Atas Talian Sepanjang Perintah Kawalan Pergerakan ( PKP) Di Daerah. Prosiding Seminar Nasional FIP (pp. 213-218).

Misyak, S., Culhane, J., McConnell, K., \& Serrano, E. (2016). Assessment for Learning: Integration of Assessment in a Nutrition Course with a Service-Learning Component. NACTA Journal, 60(4), 358-363. Retrieved from http://search.proquest.com/docview/1850644649?accountid=16788

Moore, D. E. (2018). Assessment of Learning and Program Evaluation in Health Professions Education Programs. New Directions for Adult and Continuing Education, 2018(157), 51-64. https://doi.org/10.1002/ace.20268

Munroe, M. E. (2017). Assessment and the Learning Domains, 1-12.

Nkealah, N. E., \& Africa, S. (2019). APPLYING FORMATIVE ASSESSMENT STRATEGIES IN THE TEACHING OF POETRY: AN EXPERIMENT WITH THIRD-YEAR ENGLISH STUDIES STUDENTS AT THE UNIVERSITY OF LIMPOPO. Division of Research Development and Administration, 33(1), 242-262.

Retrieved from https://www.usma.edu/cfe/Literature/Munroe_17.pdf.

Panesar-Aguilar, S., \& Aguilar, E. (2017). Promoting Effective Assessment for Learning Methods to Increase Student Motivation in Schools in India. Research in Higher Education Journal, 32, 1-16. Retrieved from

http://login.ezproxy.lib.umn.edu/login?url=http://search.ebscohost.com/login.aspx?dire $c t=$ true \&AuthType $=i p, u i d \& d b=e r i c \& A N=E J 1148914 \&$ site=ehost-live

Pelan Pembangunan Pendidikan Malaysia. (2013). Malaysia Education Blueprint 2013-2025. 27(1), 1-268. Retrieved from http://linkinghub.elsevier.com/retrieve/pii/S0742051X10001435

OECD. (2013). Student assessment: Putting the learner at the centre", in Synergies for Better Learning: An International Perspective on Evaluation and Assessment. OECD Publishing, Paris, 139-269.

Tur, G., \& Urbina, S. (2019). Rubric-based Formative Assessment in Process Eportfolio : Towards Self-regulated Learning. Digital Education Review, (35), 18-35.

Winarto, Khiyarusoleh, U., Ardiyansyah, A., Wilujeng, I., \& Sukardiyono. (2018). Pocket Book Based on Comic to Improve Conceptual Understanding of. International Journal of Instruction, 11(4), 889-900. 